\title{
Chove no Recife ${ }^{1}$
}

Maria Amelia Vilanova Neta ${ }^{2}$ Instituto Brasileiro de Geografia e Estatística, Rio de Janeiro, Brasil

Chove no Recife. Um manto de água cobre toda a cidade, e confere à paisagem o tom acinzentado dos temporais. Do alto de um prédio na rua da União, observo atentamente tudo o que se passa lá fora.

O mar, que em dias de sol apresenta os tons de verde esmeralda, em dias como esse some, completamente imerso nas colunas d'água que sucessivamente atingem a cidade primeiro uma, depois outra, logo após outra de novo. Somente nos intervalos das chuvas, quando o céu para pra descansar de tanto desabar, é que se enxerga, bem longe, seu verde tímido e opaco. Mas logo outra coluna líquida inicia seu deslocar em direção aos prédios, e todos, da zona sul à zona norte, são igualmente lavados pelos pingos d'água que bailam no ar ao sabor do vento.

E vem do vento e da chuva a música do temporal. Enquanto os pingos d'água dão a marcação constante, os ventos uivantes lhe conferem os 'solos'. Da chuva a espessura, a profundidade do som, e do vento a melodia triste e fria. Mas o vento é também expressão da ansiedade da natureza. Enquanto nas águas que caem tudo é constância chover, chover, chover - o vento é pressa e liberdade. Rodopia, passa assobiando entre as frestas das janelas, move a coluna d'água, precipita ao chão os prematuros jambos d'uma árvore da rua da Aurora. Canta, corre, canta...Parece, apaixonado, querer avisar a tudo e a todos da chegada da chuva, sua amada. Parece querer ensurdecer-nos para os sons da cidade.

Chove no Recife. Observo o balé do vento e da chuva, casal que se completa na pressa e na calma, na ânsia e na constância. E eu pacientemente olho, querendo enxergar além que a chuva fecunda o solo, e minha alma também.

Chove no Recife, chove no Recife...

\footnotetext{
1 Escrito em 16 de junho de 2004, em Recife. Inspirado humildemente no romance Homens e Caranguejos de Josué de Castro, e no poema Evocação do Recife de Manuel Bandeira.

${ }^{2}$ Geógrafa da Coordenação de Geografia da Fundação Instituto Brasileiro de Geografia e Estatística, Email: m.melvilanova@gmail.com
} 
Recebido em 25/10/2020.

Aceito em 29/10/2020.

Publicado em 07/11/2020. 